Trinity University

Digital Commons @ Trinity

Modern Languages and Literatures Faculty

Research

Modern Languages and Literatures Department

4-1996

\title{
The Second Woman in the Theater of Villedieu
}

Nina Ekstein

Trinity University, nekstein@trinity.edu

Follow this and additional works at: https://digitalcommons.trinity.edu/mll_faculty

Part of the Modern Languages Commons

\section{Repository Citation}

Ekstein, N. (1996). The second woman in the theater of Villedieu. Neophilologus, 80(2), 213-224.

doi:10.1007/BF00212101

This Article is brought to you for free and open access by the Modern Languages and Literatures Department at Digital Commons @ Trinity. It has been accepted for inclusion in Modern Languages and Literatures Faculty Research by an authorized administrator of Digital Commons @ Trinity. For more information, please contact

jcostanz@trinity.edu. 


\title{
THE SECOND WOMAN IN THE THEATER OF VILLEDIEU
}

\begin{abstract}
Best known for her prose fiction, Marie-Catherine Desjardins de Villedieu was also a successful playwright. Her three tragi-comedies (Manlius, Nitétis, and Le Favori), while significantly dissimilar in many respects, share an unusual feature. All three plays foreground the figure of the second woman, second because her role is clearly less central to the play's action than that of another woman character. In each case, the relationships between this second woman and the other characters of the play defy the traditional categories of the seventeenth-century stage. Furthermore, the second woman is not an object of desire. The differences between the first and second women are reflected and reinforced by a curious tendency in the structure of all three plays to split. Both on the level of plot and that of scenic representation, the three tragi-comedies resist unity. An examination of each of the plays reveals the links between the presence of the second woman and this structural split. The second woman, as a departure from the norms of the classical stage, becomes a significant locus for Villedieu's inscription of a personal, and distinctly female, authorial voice.
\end{abstract}

Marie-Catherine Desjardins de Villedieu (1632?-1683), was a prolific and highly successful author of novels, short stories, poetry and plays. She achieved a number of distinctions as a woman writer: she was one of the first women to support herself by writing, to receive a royal pension, and to have her plays staged. ${ }^{1}$ Her work was extremely popular well into the eighteenth century. While no doubt best known for her prose, her skills as a dramatist were considerable. In a period of four years (1661-65), she wrote her entire dramatic oeuvre: Manlius, Nitétis, and Le Favori, all tragicomedies, the first and third of which met with substantial success on stage. Le Favori was even staged for the king and court at Versailles. ${ }^{2}$

Seventeenth-century France produced few women playwrights. Women authors were largely successful as authors of novels and short-stories, and they even dominated some of the genres popular in the literary salons of the day (e.g., portraits, conversations), but throughout the seventeenth century the theater was very much a site of male influence and control. Men wrote the plays and oversaw their production. As a rule, women were merely actresses. ${ }^{3}$ Villedieu wrote her plays at the beginning of a particularly rich period of French dramatic history: the newly crowned Louis XIV was a patron of the theater, Molière and Corneille reigned on the Paris stage, and Racine was presenting his first plays. The rules and conventions governing the theater were firmly in place. This was hardly a propitious period for the emergence of discordant voices. In order to succeed in such an environment, Villedieu was obliged to write according to prevailing standards and norms. The fact that she was a woman and that the tradition in which she was writing was unequivocally dominated by male values 
had to be put aside. Writing for a public stage, it behooved Villedieu to write in a fashion suggesting gender neutrality. ${ }^{4}$ And indeed, her plays are largely models of virtual male authorship. She does not showcase powerful women; all three of her tragi-comedies are fundamentally male-centered, each presenting a male monarch whose power and initiatives determine the course of the action.

What then sets Villedieu's theater apart? What distinguishes her works from the countless plays of the period? I find this distinction in the figure of the second woman - second because her role is clearly less central to the action of the play than that of an other woman - and in the structural consequences of foregrounding a relatively secondary character. It is in Villedieu's creation of this second woman that we may, if we so choose, read a departure from the traditional norms of the classical stage, and the inscription of a personal, and distinctly female, voice. ${ }^{5}$

Each of Villedieu's three plays contains two female characters, one of whom is an essentially classic love object. In each case, this first woman character is desired by males who are themselves interconnected by traditional relationships such as filial loyalty, jealousy, and hatred. The second woman character is not desired by the males, and her relationships with the other characters defy the traditional categories of the seventeenth-century stage.

There is nothing unusual in itself about the presence of two female protagonists in a classical play. Examples of this configuration include many of the most famous plays of the century: Le Cid, Horace, Rodogune, Le Misanthrope, Tartuffe, Andromaque, Britannicus, Bajazet, and Phèdre, to name only a few. The potential list of examples is so long that it might be reasonable to venture that two women characters are the norm rather than the exception, in both comedy and tragedy. As a general rule, the identity of and relationship between the two women characters are based on standard types and oppositions. Even if such characters as Phèdre and Rodogune are hardly established types, the relationships between them and Aricie and Rodogune, respectively, are fairly standard. The two women characters may represent, for example, mothers and potential daughtersin-law who vie for the love/control of the son, or we may find young innocent women opposed to older and more cynical ones, the unloved opposed to the loved, the shrewd to the naive.

The presentation of women in standard categories and groupings is hardly surprising if we consider that these women are on stage strictly as patriarchal constructions, representations of women that reflect male and not female perspectives. Sue-Ellen Case examines how real women are suppressed into the private sphere, while the male-controlled culture invents its own representation of women, and it is these last who appear on stage. ${ }^{6}$ While the representations of male characters are constructions as well, the source of these constructions is male, thus suggesting greater realism, while certainly not precluding an idealized vision. 
In Villedieu's plays, the presence of a woman author allows for at least the possibility of a representation of women that is not an entirely male construct. It is my hypothesis that we can find a female-constructed representation in the figure of the second woman. The difference between this second woman and the first, between the second woman and all of the other characters in the play, is reflected and reinforced by a tendency, found in the structure of all three works, to split. Both on the level of plot and that of scenic representation, the three plays, to different degrees, resist unity. Rather than viewing this proclivity to split as a dramaturgical defect on Villedieu's part, it may be understood as a repercussion of combining standard and non-standard characters. By examining each of Villedieu's tragi-comedies in turn, the development of the second woman and the influence of this character on the structure of the plays will become clear.

Manlius (1661) presents a classic love triangle rendered dramatic by the force of a tyrant at one of the corners. Torquatus, the consul of Rome, and his son Manlius are both in love with Omphale, a Latin princess. Omphale is a forbidden love object for both men because she is not Roman. Despite the fact that Omphale loves Manlius, Torquatus intends to use his power to obtain her. He threatens to have Manlius put to death for having attacked and defeated the Latins without his or the Roman senate's permission. Camille is the widow of Decius, Torquatus's ally, who died heroically in battle, leaving his wife to Torquatus. Camille is not in love with Torquatus, but is offended by the latter's desire to marry Omphale rather than her, and shocked by his willingness to kill his own son. She tries to help the young lovers. Torquatus finally orders his son's death. The army revolts in an attempt to save Manlius, but Manlius affirms his father's right to have him put to death. Touched by the submissive attitude of his son, Torquatus finally relents, pardoning Manlius and sanctioning his marriage to Omphale. Camille, pleased by Torquatus's change of heart, consents to marry him.

It is clear from the simple outlines of the plot that Camille's role is not central. ${ }^{7}$ In fact she in no way influences the action of the play. She is neither the subject nor the object of desire, and holds little if any political power. I could find no mention of her in Livy, which Lancaster identifies as Villedieu's source for the play. Yet her role is not negligible: she is the only character to appear in all five acts, and she has the third largest speaking role, close behind Omphale. ${ }^{8}$ Situated outside of the love triangle at the heart of the play, Camille nonetheless remains a significant presence.

In contrast to Camille, Omphale is a standard love object: young, virtuous, and incorruptible. The age difference between them is not clear, but Omphale is a virgin, while Camille is not. ${ }^{9}$ The situation strongly suggests the possibility of rivalry between the two women: Torquatus is 
betrothed to one, but in love with the other. But this is not Andromaque. While the relationship between the two women is somewhat problematic, Omphale and Camille are both far more committed to similar notions of honor than they are to love. Thus the plot of female rivalry is never developed. Camille is shocked to learn from Omphale that Torquatus wants to marry the young captive, but quickly recovers and gives every indication of seeking to ally herself with Omphale.

Camille is a marriage pawn rather than an object of desire. She is passed from Decius to Torquatus as a "gage éternel d'une ardente amitié" (I, iii). ${ }^{10}$ And while Decius valued her highly, calling her "ce bien inestimable," it would appear that she was not an object of desire for him either. Decius chose Camille as his wife for her virtue: "Ce fut par ses vertus qu'elle engagea ma foy," (I, iii). Furthermore, Camille desires no more than she is desired. She is certainly not in love with Torquatus. Instead of being a desiring subject, Camille militates against desire. On six separate occasions Camille speaks out against love, calling it a "funeste poison" (II, vi), comparing it to a "Vipere" (I, ii), a "vaine chimère" (III, i), and a "poison des Vertus" (III, i). " The reasons for her virulent negative feelings are never explained; we are told only that "toujours mon ame ait conceu de la haine / Pour cette illusion que vous nommez amour" (III, ii).

Camille's curious diatribes against love are tied to several unanswered questions in Manlius. What is Camille's motivation? Why does she oppose Manlius's love for Omphale so emphatically on the grounds that it is illegal to marry a foreigner, and yet dismiss the law when it is a question of Manlius having gone to battle unauthorized? Why does she come to Manlius's defense against Torquatus? Lancaster reports that De Visé found Camille's conduct not properly motivated. ${ }^{12}$ Indeed, it is difficult to construct a plausible, consistent, coherent whole out of her character. This lack of coherence of character may be linked to the fact that Camille simply doesn't fit the traditional expectations of female characters. It is not an accident that critiques of the play are often linked in some way to Camille.

Camille's essential difference from Omphale is reflected in the fact that the two women rarely appear together onstage. Only twice do they do so: in the last scene of Act II and for the last scenes of the play, where Torquatus and others are present as well. The two women are split off from each other, from effectively creating an alliance, by their physical division. In a pattern we shall see repeated in the other two plays, the second woman is largely kept separate from the first.

This scenic split mirrors another such division. The onstage space seems to be identified as particularly male. First, the site of the action, Rome, is "the archetypal symbol of virile order."13 This onstage space is contrasted to an offstage space which is differentiated as female. The first words that Torquatus speaks to Camille are: "Quoy, si matin, Madame, estre hors de la Tente?" (I, i). What is implied is that he expects Camille to stay in her place, hidden and silent. Later when Camille accosts Torquatus, he again 
begins by reference to space: "Madame, quel dessein dans ce lieu vous ameine?" (IV, ii). Their relationship seems to be predicated on separate spaces, and Torquatus's surprise indicates that Camille has ventured out of her prescribed space. The second act ends with Camille and Omphale going off to Camille's tent to talk, to share what they know with each other. Camille's tent is a female space, secret, safe and intimate.

Camille then is a double figure of difference, belonging to different spaces than either Omphale or Torquatus. In terms of the action of the play, Camille's role is minor. She attacks Torquatus on moral ground, defends the young Manlius, and speaks on behalf of honor and virtue. She briefly thinks of taking action herself - stabbing Toquatus - but decides against doing so. Camille is a curious presence in a play that doesn't seem to need her. A clue to her role can be found in the denouement. Manlius was criticized for the artificality of the sudden happy resolution of all conflict. In Livy's version, Torquatus has Manlius put to death. Had Manlius died, Camille's already minor role would have become totally superfluous. Villedieu may have chosen a non-tragic end in order to give Camille a role in the play: to affirm and reward Torquatus's choice, deeming him once again worthy of her hand.

The plot of Nitétis (1663) is more complicated than that of Manlius, yet the two plays have significant similarities: the tyrant, the love triangle, the conflict between honor and desire, and of course the second woman. As the play opens, Cambise, the king of Persia, is planning to divorce his wife Nitétis in order to marry his sister Mandanne whom he loves. This incestuous union is opposed by everyone, including Mandanne, who is in love with Prasitte. Nitétis, who is virtuous in the extreme, opposes Cambise's plans only because she wants to prevent him from committing a crime. Before marrying Cambise, Nitétis had been in love with Phameine, who is now Cambise's prisoner. When Smiris, brother of Cambise and Mandane, objects too strongly to Cambise's plans, Cambise has him killed. Meanwhile Phameine escapes from prison and visits Nitétis. Cambise finds them together, and despite Nitétis's complete innocence, the tyrant plans to torture Phameine to death in front of her. Before any action can be taken, the people arise in anger over the murder of Smiris. Cambise is on the defensive. Nitétis frees Phameine and asks him to defend her husband. But when Cambise sees Phameine approaching at the head of a group of guards, he believes them to be his enemies, and commits suicide. Mandanne, jubilant at the death of her tyrannical brother, plans to marry Prasitte and ascend the throne. In contrast, Nitétis refuses to marry Phameine. She will not profit from her husband's death by marrying his enemy.

Despite the fact that her name is the title of the play and that she speaks the greatest number of lines, Nitétis is still the second woman. In the central 
triangle - Cambise, Mandanne, and Nitétis - it is she who is not desired. Like Camille, Nitétis has no real political power; unlike her, Nitétis does act. She frees Phameine and sends him to defend Cambise. However, the outcome of her actions - Cambise's death - was not what she sought. Like Camille, she is a marriage pawn in the hands of men, and also outside the usual channels of distribution. It is not fathers who give away Camille and Nitétis. Camille is given away by her husband before he dies, while Nitétis was given to Cambise under complicated false premises by the ruler of Egypt. ${ }^{14}$

Like Omphale, Mandanne is a young, innocent love object. The opposition between the two women in Manlius on the basis of virginity holds here as well. The relationship between them would suggest rivalry, but in Nitétis, there is not the slightest hint of any such feelings. While their relationship does not fit neatly into clear categories of love or enmity, Mandanne makes an unambiguous move to establish an alliance between them by saying: "Qu'entre nous desormais la feinte soit bannie, / J'aime vostre vertu" (I, ii). The scenic disjuncture of the women that we noted in Manlius is exacerbated here. Nitétis and Mandanne are on stage together only at the beginning and end of the play. Between I, iii and vi, ii they are not only not on stage at the same time, but they do not even share acts. Their plots separate and run independently until the end of the play. This splitting and symmetry are paralleled by the situation of the two suitors, Phameine and Prasitte, who literally have no contact with each other until the final act.

Nitétis is honorable, devoted, and self-denying. Her loyalty to Cambise is excessive, as are the terms in which she describes it to him: “. . . j'abhorre ta personne, / Et que si dans ta place un monstre avoit ma foy, / Il auroit dans mon coeur le même rang que toy, / C'est en toy mon honneur et ma gloire que j'aime" (III, ii). She makes no attempt to stop Cambise from divorcing her, she refuses to listen to Phameine's protestations of love, and she will not marry him when Cambise is dead. While Nitétis's stance of honor and allegiance is exemplary of the patriarchy, it simultaneously represents an original attitude for a female character of the classical stage: almost total refusal. She completely rejects the male world of power and marriage. The males in her life - Amasis and Cambise - have victimized and betrayed her. Even Phameine, her devoted suitor, has done nothing to protect or save her from either his father or her cruel husband. In fact, it is she who must save Phameine, leading a charge of guards to liberate him.

The role of the second woman in Nitétis is larger than it was in Manlius. Nitétis embodies the virtues she ascribes to, including that of unquestioning devotion to one's husband, which leads her to passivity, and a belief in justice, which leads her to the action of liberating Phameine. Above all, she refuses all values that are not hers, taking a firm stand independent of those around her. She is far more central to the play than was the case 
with Camille, but Nitétis too could have been written without this second woman. What she brings to the play is a strong moral focus as well as complexity. While she may play the part of pure virtue to Cambise's black villainy, ${ }^{15}$ her presence increases the ambiguity of the play as a whole. Her choices lead to further questions rather than resolutions. Who is responsible for Cambise's death? Shouldn't she have known better than to send Phameine to save him? How are we to interpret her decision not to marry Phameine?

Gethner formulates a question in his discussion of this play which points to the curious centrality of the second woman in Villedieu's theater. He asks: "Why, given the considerable amount of stageworthy material in the life of Cambyses, whose name was well known to French audiences of the period, should Desjardins have opted to focus on his wife, about whom Herodotus says next to nothing?"16 I believe that it was precisely the figure of the wife of the tyrant that was of interest to Villedieu.

Le Favori presents a totally different dramatic universe: where the first two plays were tragi-comedies in the sense that tragedy was narrowly averted, here we find a far more comic universe, albeit with dark undertones. Moncade, the King of Barcelona's favorite courtier, is unhappy with his position. He is harassed by flatterers, painfully aware of the precariousness of his position, and unable to find the solitude to court the woman he loves, Lindamire. The king has noticed his dissatisfaction, and insists on being told the reason for it. When Moncade admits his love for Lindamire and his frustration in not knowing whether he is loved in return, the king reacts with displeasure. Meanwhile, Moncade is accosted by two flatterers, Clotaire, an exiled prince, and Elvire. Elvire, the second woman, has admitted to her confidant that she desires Moncade. When the king withdraws his favor from Moncade and exiles him from court, both Clotaire and Elvire quickly desert the young man. Hoping to profit from the situation, they go even further and accuse Moncade of plotting against the king. Lindamire, however, sincere in her love for Moncade and unhappy at court as well, takes this opportunity to declare her feelings, and announces her intention to follow Moncade into exile. Alvar, Moncade's friend, is equally loyal. The play concludes happily with the king's revelation that he was feigning anger in order to induce Lindamire to declare her love for Moncade. Full favor is restored to Moncade while Clotaire stalks off the stage and Elvire finds a new suitor.

In some ways, Elvire is even less important to the dramatic action than either Camille or Nitétis. She neither is nor was anyone's wife; in fact she is not anchored to any male in the play. She speaks far fewer lines than Camille or Nitétis. ${ }^{17}$ And once again, she is largely superfluous to the specific action of the play. She seeks to prevent Moncade and Lindamire 
from meeting alone, and she hopes to persuade the king that both Lindamire and Moncade are guilty of some crime, but she is largely ineffective with both projects. The triangle in this play is between Lindamire, Moncade, and the king; like Camille and Nitétis, Elvire is essentially de trop.

The play, however, was originally entitled La Coquette ou le Favory. The "coquette" in question can be no one but Elvire. That Villedieu chose to place this character in the title (and first), as she did Nitétis, is a clear indicator of the importance of Elvire's role. Indeed, Elvire dominates Acts II and IV, and alone on stage with her confidant, she opens these two acts with scenes of over ninety lines each. The original title is indicative as well of the double subject of the play, and, underlined by the word $o u$, this double subject's undecidability. Typically, titles of plays of the period which have the form $X$ ou $Y$ refer either to a character and a situation (e.g., Dom Juan ou le Festin de pierre) or refer to one character alone (e.g., Tartuffe ou l'Imposteur). To refer to two characters in the title using ou instead of et (e.g. Phèdre et Hippolyte) is to announce a significant deviation from the classical norm of unity.

Lindamire is a relatively typical female protagonist, similar to the leading women in Villedieu's earlier plays. Her love is sincere and pure, and she has no ulterior motives. Lindamire presents a variation, however, by hiding her love from Moncade while he is in favor. She is jealous of the court and fears that her own interest in him could be interpreted as self-seeking. But her reserve is put aside when Moncade's fortune changes, and her devotion remains unswerving.

The potential for rivalry between women protagonists is explicit in $L e$ Favori. Elvire presents herself as Lindamire's rival for Moncade. However, the spectator quickly realizes that she does not constitute a serious threat in that role when Moncade's first reaction to seeing Elvire is: "Ah rencontre importune! / Que je haï cette femme" (II, ii). But in fact the rivalry that Elvire manifests has little to do with Moncade; Elvire is interested in him only because she hates Lindamire. What seems like a strong potential conflict between the two women quickly evaporates however. Elvire seems incapable of taking anything very seriously, including love and hatred, and she spends much of her one scene alone with Lindamire (III, iv) consoling her rival after Moncade's disgrace: "Grondez pour soulager un si cruel martyre; / Là je suis vostre amie, et vous pouvez tout dire" (III, iv). Elvire is a curiously ambiguous character. On the one hand she seems to be a villain: she is venal, eager to undermine Lindamire's relationship with Moncade and even to betray her to the king. But her villainy is not sustained, and her generosity and independence of thought provide her with a contradictory positive coloring.

In Villedieu's other two plays, the second women parrot the patriarchy in their discourse of honor and strict virtue, and both refuse sexual desire. Elvire, on the contrary, is an actively desiring subject. In fact, she desires indiscriminately, attaching herself to the first man who comes along after Moncade falls into disfavor. She does not accept the pliant and passive 
role assigned to her by the patriarchal culture, or the male ethos of fidelity. These patriarchal values are articulated by Elvire's confidant Léonor, who calls Elvire a "coquette." Elvire, allowing that the term might be apt, thus accepts a place outside of the mainstream. She does so in the name of her own pleasure: "Je fais moins pour autruy, que je ne fais pour moy" (II, i). She articulates a set of values clearly opposed to those of the other characters of the play, valuing only the present moment and enjoyment. ${ }^{18}$ Reminiscent of Corneille's Phylis (La Place royale) in her devotion to pleasure and multiple lovers, she ends up quite differently. Phylis dutifully marries Cléandre at the end of Corneille's comedy, while Elvire remains perfectly unattached.

As in Villedieu's other plays, the two women protagonists rarely share the stage. They are together only in III, iv and for two scenes at the denouement. Here their separation can be understood as a replication of their different values. The two women do not seem to belong to the same world. Elvire does not understand Lindamire's pain, nor her loyalty to Moncade: "J'ignorais que ce mal eût tant de violence, / Ne l'ayant jamais sceu par mon experience" (III, iv). Her own flightiness in love is diametrically opposed to Lindamire's modest and loyal desire for Moncade.

Le Favori gives the impression of being split to an even greater degree than Manlius and Nitétis. In part this impression is due to the greater opposition between the two women protagonists. This opposition extends to the play itself: Le Favori presents a curious alternation between a tragicomedy depicting the problems of love and sincerity, and a comedy of play-acting and flirtation. The cleavage within the play is introduced rather abruptly when the second act opens with Elvire and Léonor. Their lengthy scene is jarring because we have neither seen nor heard speak of either of them in the first act. Their discussion of coquettry provides a disconcerting juxtaposition with the last scene of the first act, in which the king's displeasure with Moncade had been announced. While split, the play remains nonetheless balanced: Lindamire dominates Acts III and V, while Elvire dominates Acts II and IV; each is on stage for the same number of scenes in the entire play. Thus Elvire, like Camille and Nitétis, remains somewhat removed from the main dramatic action.

Elvire's role in Le Favori is, however, crucial, certainly more so than that of her female counterparts in the two earlier plays. Through her relationships with the other characters, she points to certain hidden and jarring elements. Her rivalry with Lindamire which evaporates so quickly is a sign of a more potent rivalry in the play, that between the king and Lindamire for Moncade's affections. Elvire's venality and love for the court seem at first totally opposed to Moncade's lofty sentiments. But despite his protestations, he is as much a creature of the court as Elvire. In contrast to Clotaire, who is a fawning, treacherous hypocrite, Elvire appears, as Gethner has noted, forthright and lucid about her motives and beliefs. ${ }^{19}$ Clotaire leaves the court (or at least the stage) in disgrace in the last act, while Elvire remains. She will adapt; and she has already found a new lover. 
While Lindamire wins Moncade, Elvire manages to call into question the exalted sentiments uniting them. Lindamire waxes lyric about her love for Moncade: "C'est sa haute vertu qui me le fait aimer, / Seule d'un feu si pur elle est l'illustre cause" (V, vi, 1368-69). Although Lindamire's words were directed at the king, it is Elvire who rejoins: "Que le parfait amour est une sotte chose, / Vive l'amour commode et la bonne amitié" (V, vi). Through their opposition, the two forms of discourse work to undermine each other; Elvire has the distinct advantage of speaking last. During the first act, the focus of the play is clearly on the men, Moncade and the king. After that, until Act V, scene vi, when the king announces his deception and restores his favor to Moncade, Lindamire and Elvire have had the dominant roles. As Act V draws to a close, the focus is once more on the relationship between the males. Lindamire is reduced to a pawn between them and Elvire is totally superfluous. But once again, Elvire triumphs: she remains on stage alone with Léonor for the final scene of the play. Elvire has the last words, and with them she dismisses the entire action of the play: "Tout cela ne vaut pas la peine d'en parler, / Et Dom Lope m'attend qui m'en va consoler." (V, viii). She remains free and in control of her life.

Elvire's presence prevents Le Favori from being a simple tragi-comedy. Villedieu uses Elvire to call into question not only the values of the patriarchy, but also the conventions of the classical stage, particularly that of unity.

Camille, Nitétis, and Elvire are all original women characters outside of the mainstream of the male dramatic production of the day. None is primarily an object of desire, and all are in some sense, perhaps as a consequence of the absence of desire, not the primary forces directing the dramatic action. The splits in Villedieu's plays can be read as an indicator of the difficulties of integrating women within the male dramatic universe. Verdier, in discussing Villedieu's Mémoires de la vie d'Henriette-Sylvie de Molière (1674), says that the confident first-person narrative voice of the narrator "dramatized the writer's revolt against literary bondage as well as her successful struggle to free herself from the slavish imitation of models in order to liberate a new genre of prose fiction." ${ }^{20}$ We can see the same impulse at work in Villedieu's theater as she stakes out territory within the male models of theater for her own voice. Unfortunately, she stopped writing for the stage after only three plays, and so she did not go far enough to liberate a new genre of theater. The second woman is the site of the beginnings of such a liberation.

Department of Modern Languages

NINA EKSTEIN

Trinity University

San Antonio, TX 78212

U.S.A. 


\section{Notes}

1. I am relying on Gabrielle Verdier for this historical information; "Madame de Villedieu and the Critics: Toward a Brighter Future," in Actes de Wake Forest, Ed. Milorad R. Margitic and Byron R. Wells (Tübingen: PFSCL, 1987), p. 324.

2. This production was also a first for a woman playwright.

3. It is worth noting that in Elizabethan England, as well as in ancient Greece, women were not allowed on stage. Their parts were played by boys. Women were thus excluded from all aspects of dramatic production.

4. Henriette Goldwyn notes: "Son projet théâtral est téméraire dans la mesure où elle a choisi un genre qui, jusqu'à elle, n'avait jamais encore reconnu en tant qu'auteur consacré une femme." ("Manlius - l'Héroisme inversé," in Actes de Wake Forest, ed. Milorad R. Margitic and Byron R. Wells [Tübingen: PFSCL, 1987], p. 423).

5. Elizabeth Berg articulates the issues very clearly: "Caught in a masculine tradition - one might say a masculine language - and responding necessarily to masculine demands, women writers must assume a phallogocentric system of representation while at the same time attempting to inscribe their own language or figure in their own work. Like male writers, but for other reasons, they must both reproduce the masculine system of representation and attempt to introduce (or produce) an other figure within their representations" ("Classical Depictions: Figures of Woman in French Classicism," diss., Cornell University [1982], pp. 177-8).

6. Feminism and Theatre [New York: Methuen, 1988], p. 7). Jill Dolan points out that "the female body is imaged within representation only as the site of male desire" (The Feminist Spectator as Critic [Ann Arbor and London: UMI Research Press, 1988], p. 99). In the context of the theater, male desire is manifested through the gaze of the (male) spectator. Case notes that "in the realm of theatrical production, the gaze is owned by the male: the majority of playwrights, directors and producers are men." (p. 118). Laura Mulvey has closely examined the workings of the multiple gazes in cinema (which have important implications for the theater), and she suggests in her conclusion that visual pleasure must be eradicated in order to inscribe women in representation ("Visual Pleasure and Narrative Cinema," Art After Modernism: Rethinking Representation, ed. Brian Wallis [New York: New Museum of Contemporary Art, 1984], p. 373). Finally, Barbara Freedman points out that Lacan argues that woman does not exist except as a fantasy or theatrical construct ("Frame-Up: Feminism, Psychoanalysis, Theatre," in Performing Feminisms. Feminist Critical Theory and Theatre, ed. Sue-Ellen Case [Baltimore and London: Johns Hopkins Press, 1990], p. 64).

7. De Visé criticized the character of Camille for this reason: "le rôle de Camille est ... inutile" in his Défense de la Tragédie de Sophonisbe, cited by Claude and Fraçois Parfaict, Histoire du théâtre fançois (1734-49; Geneva: Slatkine Reprints, 1967), Vol. II, p. 381.

8. Camille has 345 lines, while Omphale has 383.

9. Camille is in fact a member of an unusual category (another rerpresentative of which we will find in Nitétis): non-virgins who are not mothers.

10. Manlius (Paris: Barbin, 1662; Geneva: Slatkine Reprints, 1971). All reference will be to this edition.

11. See also III, ii and IV, ii.

12. French Dramatic Literature in the Seventeenth Century (New York: Gordian Press, 1966), Pt. III, V. 2, p. 561. De Visé was highly critical of Camille: "le Spectateur ne sçait plus qu'elle [sic] intérêt elle a dans la pièce," in Parfaict, p. 381.

13. English Showalter, "Writing Off the Stage: Women Authors and Eighteenth-Century Theater," in Displacements. Women, Tradition, Literatures in French, Eds. Joan DeJean and Nancy K. Miller (Baltimore: Johns Hopkins University Press, 1991), p. 153.

14. Amasis had killed all of Nitétis's family when she was very young and usurped the Egyptian throne. He kept Nitétis in his family and planned to marry her to his son Phameine. But when Cambise asked to marry Amasis's daughter, Amasis substituted Nitétis for his own daughter, who had died.

15. Perry Gethner interprets this moral opposition between Nitétis and Cambise as the 
means Villedieu employs to rewrite history in order to bring to light a type of female heroism that traditional historians fail to mention ("Melpomene meets Women Playwrights in the Age of Louis XIV," Neophilologus 72 [1988]: pp. 18-19).

16. Gethner, p. 18.

17. Elvire has 255 lines as opposed to 345 for Camille and 397 for Nitétis.

18. Gethner views Elvire as a spokesperson for a new generation. He finds her to be totally amoral and apolitical, with no regard for the traditional code of honor. Instead she propounds a philosophy based on love of self, love of the court, and love of joy ("Love, Self-Love and the Court in Le Favori," in Actes de Wake Forest, eds. Milorad R. Margitic and Byron R. Wells [Tübingen: PFSCL Biblio 17, 1987] p. 408).

19. "Love, Self-Love," p. 410.

20. Verdier, p. 333. 